\title{
NEW ZEALAND'S BICULTURALISM AND THE DEVELOPMENT OF PUBLICLY FUNDED RONGOA (TRADITIONAL MAORI HEALING) SERVICES
}

\author{
Tony O’Connor
}

\begin{abstract}
The establishment of publicly funded Rongoa services was made possible by a bicultural model of government. My aim was to examine how biculturalism played out through that process. To do that I drew on eighteen months of working with some Rongoa healers and three interviews with government employees developing Rongoa services. What emerged from the development process was a certain form of Rongoa that some Maori did not recognize as either 'authentically Maori' or particularly useful as a form of health care. There appeared to be limits as to how 'Rongoa's' take on the public purse could be justified and hence how Rongoa could proceed into the future as a governmentfunded health service. For Rongoa to form part of New Zealand's publicly funded health system it had to be complementary to (as in different, but not too different) from the kinds of health concepts that had already been publicly validated. Silenced by the development process were some concepts, practices and relationships that said much about how cultural-pluralism in the field of health was managed under a bicultural model of government.
\end{abstract}

\section{INTRODUCTION}

The establishment of publicly funded Rongoa services was made possible by a bicultural model of government. According to New Zealand government policy, a bicultural model of government is one that is based on the principles of the Treaty of Waitangi (Te Puni Kokiri 2001). A literature review, three interviews with some government administrators and eighteen months of fieldwork at a Rongoa clinic in urban Auckland suggests to me that there are other principles and relationships of power underlying the bicultural government of New Zealand's publicly funded health services. My research shows that the collectives and individuals developing a publicly fundable form of Rongoa 
had to take into account the numerous interests of the many actors involved in developing a form of Rongoa that can complement the health services that were already publicly funded in New Zealand. The form of Rongoa that has emerged from the development process has been well received by some healers, but it has also been criticized by some of the 'most traditional' (pers. comm. government administrator 2005) of Maori healers. Thinking about Rongoa as 'a range of culturally bound responses' to illness (Ministry of Health 2006:2) would not help understand why a form of Rongoa that marginalises some of the 'most traditional' of Maori healers has been funded by the Crown. Instead, I have thought about the form of Rongoa that publicly funded practitioners are contracted to deliver as a form of healing shaped by the context in which it has emerged.

\section{BICULTURALISM}

Biculturalism has been used to refer to many different kinds of relationship between the indigenous Maori and the settler population of New Zealand. I am using the term biculturalism to refer to the government's Treaty of Waitangi based development of Rongoa services. Since the signing of the Treaty of Waitangi in 1840, New Zealand has officially been a member state of the British Commonwealth, and the Maori people citizens of the British Monarch (Belgrave 2005; Orange 1987). Officially, the Head of State is the British Monarch but in reality the Monarch has ever since 1840 remained little more than the figurehead of the nation. The Treaty has been interpreted as many things over the years, including 'a simple nullity' by a Chief Justice and Bishop in 1877, and 'the founding document of the nation' by a Minister of Health in 1990, and many other political leaders since (Kolig 2004). Today it is listed as one of the nation's five constitutional documents (Ministry of Justice 2006), and is by far the most controversial of these (e.g. Brookfield 1999; Durie 1998; Rata 2005).

The word 'Maori' was first used to refer to the many tribes of New Zealand's indigenous people as 'ordinary folk' at the signing of the Treaty of Waitangi in 1840 (Walker 2004:94). Since then the construction of a pantribal identity has involved the input of Maori and non-Maori activists, academics and government officials (Sissons 1993; Walker 2004). The New Zealand origins of the term 'biculturalism' has been traced to the 1930s scholarship of one of the most influential Maori leaders of the twentieth century, Sir Apirana Ngata (Sissons 2000). But Ngata did not suggest a bipartite constitution of government through his use of the term. Instead, Ngata's biculturalism served as a counter to the government's 'assimilationist' policies. Ngata's biculturalism involved the engineering of a 'Maoritanga' - an idealized pantribal concept 
of Maori culture. Through his role as Native Affairs Minister, Ngata used the concept of Maoritanga to facilitate a traditionally inclined 'bicultural' adjustment of Maori to the conditions of New Zealand's emerging capitalist society. Despite Ngata's efforts, the average health and socioeconomic status of Maori continued to decline, but his work to strengthen a common identity that went beyond tribal differences would remain.

A bicultural model of government is argued to have emerged in response to Maori protest during the late 1970 s and early 1980 os about the government's interest in developing New Zealand as a multicultural society (Bozic-Vrbancic 2003; Sissons 2000; Walker 1996). Maori leaders could also foresee that they would struggle to have their historical and contemporary concerns addressed if the government officially pursued a multicultural agenda. In 1975 the passing of the Treaty of Waitangi Act established the Waitangi Tribunal to hear grievances against the Crown; grievances which were becoming harder to ignore from a legal and political perspective as Maori were graduating from Universities and gaining legal and governmental expertise, and greater numbers of Pakeha were becoming more accepting of protesting Maori's arguments (Walker 2004).

The fight against a multicultural sentiment has to some extent been successful, certainly within the arena of health. The 1980 os and 1990s were important decades. In 1985 the Government's Board of Health's Standing Committee on Maori Health recommended that the three articles ${ }^{2}$ of the Treaty of Waitangi should be regarded as the foundation for good health in New Zealand (Dow 1999: 14). This was followed up in 1988 by the Director General of Health's statement that ' $[c]$ oncepts of health are firmly based in Maori culture (which according to the Treaty, have a right to official recognition and protection)'. Furthermore, the Director General argued, 'Maori people have a right to appropriate services funded through our health system' (Salmond cited in Durie 1998: 85). ${ }^{3}$ A few years later the Director General of Health and the Director of the Medical Research Council jointly proposed that ' a truly bicultural perspective in policy, service development and delivery should contribute towards the ultimate elimination of the existing gaps between the health status of Maori people and that of the general population' (Salmond and Hodge 1988: 8). Currently, the Ministry of Health's Maori Health Strategy seeks to 'fulfill the special relationship between Maori and the Crown under the Treaty of Waitangi'. (Ministry of Health 2000: vii).

As of the late 1980 os the government's bicultural policies have been based on 'the principles' of 'the' Treaty of Waitangi, ${ }^{4}$ which were formulated during the 
1980s. The Treaty of Waitangi Act (1975) gave the Waitangi Tribunal statutory authority to determine the principles of the Treaty but as it turned out the Tribunal did not act alone in determining the Treaty's principles; numerous other government and nongovernmental commissions and committees arrived at their own interpretations, all of which have been considered in determining the principles of the Treaty. That there were in fact 'principles' of the Treaty to determine was then and is still now debated, as are the substance and accuracy of the emergent principles - 'partnership', 'participation' and 'protection'. The Ministry of Maori Development has published a thirty-two page report discussing how these principles have been interpreted in various government and judicial contexts (Te Puni Kokiri 2001).

The principles of the Treaty were first inserted into health legislation in 1993 through the New Zealand Public Health and Disability Act 2000. The 1993 Act was updated in 2000, which the Ministry of Health reads as 'adopt[ing] measures that recognise and respect the principles of the Treaty of Waitangi in the health and disability support sector' in 'response to the Crown's desire to have greater Maori participation in the health and disability support sector with a view to improving Maori health outcomes, and reducing health disparities between Maori and other population groups' (Ministry of Health 2005). But epidemiological records show that despite twenty years of enhancing the machinery of bicultural government, Maori continue to die younger and suffer more sickness than Pakeha even within socioeconomic deprivation indices (Reid et al 2000). Furthermore, despite the particulars of specific cases, some scholars contend that, overall, biculturalism works as 'an ideology ... of co-option ... promoted by the state in an effort to contain Maori demands for greater autonomy' (Sissons 2005:28; Durie 1998). Others see 'bicultural' government benefiting a 'neo-traditional Māori elite' and as having to some degree outrun the control of Pakeha parliamentary and judicial leaders (Rata 2004: 73; Kolig 2004).

The requirements of biculturalism have been written into the Maori Health Directorate's Rongoa project plan. The Directorate states that the relationship between Maori and the Crown will proceed with 'Maori participation at all levels; active partnership in service delivery; protection and improvement of Maori health status' (Maori Health Directorate 2004: 12, repeating the New Zealand Health Strategy (Ministry of Health 2000: 8)). Underlying this relationship is 'the premise that Maori should continue to live in Aotearoa ${ }^{5}$ as Maori' (ibid.:7). Jones (2000a: 108) has argued that although the 'partnership' between Maori and the Crown in the government of health is in reality dominated by Western models of health, providing Rongoa services will improve Maori people's 
access to their 'cultural resources' ( representing 'participation'). Such a partnership should involve ensuring that the intellectual property rights of Maori are not violated (representing 'protection'). It is worth noting that Jones, the principle of 'protection' does not just refer to the Treaty partners' responsibility to protect Maori people's health status (ibid.), as it seems to for the Ministry of Health and Maori Health Directorate (Maori Health Directorate 2004: 12; Ministry of Health 2000: 8); 'protection' also refers to the Treaty partners' responsibility to protect the intellectual property of Maori. If Rongoa healers' concepts of health, illness and healing are thought of as intellectual property of Maori, my findings show that what constitutes intellectual property worthy of protection is contested by Maori and the Crown. I also show that there are a number of strategies employed by Maori to protect intellectual property.

Given that many writers have noted that the outcomes of bicultural policies often differ to the ideals of biculturalism, it is useful to ask, how the development of a publicly fundable Rongoa has actually played out in practice? By doing so we may learn about some of the 'silent' relationships of power and concepts underlying New Zealand's biculturalism.

THE BICULTURAL DEVELOPMENT OF RONGOA SERVICES

Maybe the most important indicator to date of Maori 'participating' in the delivery of state funded health services 'as Maori' is that by early 2006 there were twelve government funded Rongoa clinics in operation nationwide. Before I move on to discuss the model of Rongoa these clinics are expected to deliver, I need to review some important events that led to the development of state funded Rongoa services. The many actors and forces that have contributed to the development of a publicly fundable form of Rongoa have been shaped by firstly a colonial process that foresaw the brightest future of Maori as one where they were assimilated into Pakeha culture, then a 'postcolonial' Treaty of Waitangi based bicultural process that foresees the brightest future of Maori as one where they are able to remain citizens of the Crown while maintaining a strong Maori identity. The bicultural process involves what Sissons has referred to as a process of 'traditionalisation', which is a long term process leading to the reification and romanticisation of selected cultural forms through the convergence and conflict of many actors and forces (1993:1). Traditionalisation subordinates 'individual agency' to 'social processes of objectification and rationalization' (Sissons 1998:98), which has seen the codification and standardisation of Rongoa take place within the context of biculturalism.

With the graduation of the first medically trained Maori doctors there was a 
shift of authority in the field of Maori health from Pakeha colonial officials to medically trained Maori. However, this shift did not bode well for the security of 'tohunga', which in the context of healing has been defined as expert, chiefly, priestly healer (Williams 2003: 431). The three most prominent Maori leaders at the time, Maui Pomare, Te Rangi Hiroa Buck and Apirana Ngata worked to further certain aspects of the Maori way of life and society, but the role of tohunga as healer was not one of them (Dow 1999; Laing 2002).

By the turn of the century it was clear that tohunga were proving ineffectual at curing the introduced infectious diseases decimating the Maori people. But many Maori were still turning to tohunga for health care. A Tohunga Suppression Act was passed in 1907 with the support of Ngata, Pomare and Buck because they anticipated benefits, including the protection of Maori health, if the Bill could be passed. ${ }^{6}$ Healers were convicted under the Act, in particular tohunga deemed to be 'fraudulent', or in other words those 'healers' who posed as 'tohunga' that 'possess[ed] or pretend $[e d]$ to possess supernatural powers' (Dow 1999: 128).

The Tohunga Suppression Act stopped short of outlawing Maori healers' use of herbal remedies (Laing 2002:157) and physical manipulations, ${ }^{7}$ and no other Act was passed to restrict such activities. I find this a most interesting quality of the Act because it may show that some Maori healing knowledge and skills have long been considered promoting of, or at least not endangering of, good health by New Zealand's health, political and judicial leadership. If the omission of Maori herbal remedies and physical manipulations from the Act was purposeful, it constituted what I consider to be an early act of governmentality (Foucault 1991) with the purpose of establishing an acceptable form of Rongoa; a process that is continuing today.

By the 1950s, land confiscations ${ }^{8}$ and the attractions of waged labour had driven large numbers of Maori into urban areas, distancing the majority of Maori from their traditional economic bases and social structures (Metge 1964; Walker 2004; Webster 1998). A number of Maori protest groups had organized themselves as effective mouthpieces of Maori disenchantment, especially in urban areas, and now New Zealand's politically influential nonMaori population had firsthand exposure to the basis of protest about the socioeconomic and health status of Maori. An infrastructure of medical and socioeconomic surveillance had been established by the mid twentieth century, especially in urban areas, which provided hard data to government about the suffering of large numbers of Maori. By the 196os the Department of Health was showing a willingness to act on its growing awareness that Maori people suffered 
poor health in comparison to the health of Pakeha. The Department now accepted that there were 'adverse environmental conditions [which] give rise to consequential disadvantages in health ... for many Maoris' (Ian Prior cited in Dow 1995:197), a position strongly supported by a 1960 report that damned the Department of Maori Affairs for its systematic disadvantaging of Maori (Department of Maori Affairs 1960). Many discriminatory Acts and policies were subsequently dropped, including the Tohunga Suppression Act.

During the 1970s New Zealand's health leadership's long-standing opposition to alternative therapies was 'softening' (Dow 1995: 154). Health administrators throughout the 'Western' world were becoming interested in the implications of 'lifestyle' for health planning and its effects as a determinant of health and illness. Alongside the lay public they were becoming cynical of the apparently empty promise of biomedicine to provide good health for all and women especially were becoming tired of men's domination of the health sector (Black, Boswell et al 1988; Dow 1995). Rongoa healers would by the end of the century emerge as one of a number of 'complementary' or 'alternative' healers receiving government money for the provision of health services. ${ }^{9}$

The Ministerial Advisory Committee on Complementary and Alternative Health advised that Rongoa not be administered as a complementary or alternative (CAM) therapy ${ }^{10}$ because of the government's commitment to developing a health sector based on the Treaty of Waitangi (Ministry of Health 2003:2). This sentiment has its roots several decades past. It was in the context of rising dissatisfaction at the suffering and structural disadvantaging of Maori that the government established the previously mentioned Waitangi Tribunal in 1977 to advise it on the veracity of a rising number of claims that it had breached obligations the Crown had made by signing the Treaty of Waitangi. Early on the Waitangi Tribunal established the fundamental points of the Treaty, such as the guarantee that Maori chiefs had the right to their spiritual and cultural values and that the Crown carried a responsibility to ensure Maori had access to them. These findings secured a place for Maori cultural and spiritual values equal to those of the majority in the deliberations of the nation's government, which Levine (2005:108) argues, came to define the agenda of 'biculturalism'. The significance of the Tribunal's findings were cemented in the health sector during the early 1980 os following a series of meetings between health leaders that traditional Maori notions of health, illness and healing were protected by the Treaty of Waitangi (Durie 1998: 81-84).

Of further significance is that in 1993 a committee was established to help constrain the skyrocketing cost of New Zealand's state funded health services. This 
Committee received the first ever formal communication between traditional Maori healers and central government (Durie et al 1993). The communication took the form of an advisory that Rongoa form part of the 'core' of health services that everyone (Maori and Pakeha) would have access to without having to pay. The advice was accepted. This effectively laid the foundation for the later development of publicly funded Rongoa services (Durie 1998: 87). The acceptance of this advice must be seen as at least partially influenced by four developments concurrent with legislative change. First, but not necessarily primarily, a global interest in exploring the contribution traditional healing systems could make alongside the biomedical system (World Health Organisation 1977); secondly, the New Zealand government's concern about the discrepancy in health status between Maori and nonMaori peoples (Pomare 1988); thirdly, the government's 'renewed' commitment to a bicultural health sector and acceptance that 'culture' was relevant to health; fourthly, because financial cost was high on the Core Health Services Committee's agenda, Rongoa may have been perceived as an attractive proposition because being 'low-tech' it had a potential to prove efficacious in terms of cost-benefit analyses (cf Dew 2003:109-110).

An important example of the bicultural 'partnership' between Maori and the Crown in the development of publicly funded Rongoa services, is the relationship between the national board of Maori healers - Nga Ringa Whakahaere o te Iwi Maori - and what is now the Maori Health Directorate. During the late 1980 s and early 1990 os some Department of Health employees took part in establishing what became in 1993 Nga Ringa Whakahaere o te Iwi Maori (pers. comm. Tricia Laing 2003). Today the Board advocates on behalf of traditional Maori healers nationwide. According to the Directorate the 'majority of known healers' support the Board (Maori Health Directorate 2004: 6); but I have been told by a number of healers and other health sector workers that the Board's support has fluctuated significantly over the years. The establishment of the Board opened up an essential channel of communication between healers and the government. It meant the heterogeneity of traditional Maori healing (Buck 1970; Jones 20oob; McLeod 1999; Parsons 1985) could potentially be brought within a framework of symbolic order so that government administrators could hold healers accountable for their use of public funds. By agreeing to how health and illness will be defined and how healing will proceed, as is now described in the Rongoa services' contracts, the healers would know exactly how they would be held accountable for their use of public funds, or in other words, what the bounds of acceptable healing are. The process of establishing this range of normal behaviour can be thought of in terms of manufacturing and maintaining patterns of consciousness and subconsciousness, uses of the body, perceptions of morality, health care practices and so on, made possible 
by coordinating dispersed and institutionalised mechanisms of social control (Foucault 1991). There would need to be coordination 'between the bottom and the top' (Gramsci, 1971:5, 52) if the development of Rongoa services was to be effective and enduring. The Ministry of Health's Maori Health Directorate was responsible for ensuring this occurred. They worked closely with the national Board of Maori healers for the purpose of trying to reach agreement on a set of healing and administrative procedures and accountabilities that would retain a consensus between not only the government's health authorities, healers and their clientele, but also the voting public, because health sector funding, particularly the funding of Maori health, attracts a great deal of political and public interest in New Zealand.

MODELLING A FUNDABLE FORM OF RONGOA

The healers I came to know often discussed the meaning of 'traditional' (Linnekin 1983) healing. For instance on one occasion some healers had great fun making jokes about the concept ' $\mathrm{La}$ ' (which they considered to be 'not traditionally Maori' as, for example, there is no ' $\mathrm{L}$ ' in the Maori alphabet), which a healer they knew intended to discuss as part of a course on 'traditional Maori healing' she would be teaching at a Natural Therapies College in urban Auckland. Decisions about what exactly traditional healing is has had to be made at the level of government for the purposes of signing up healers to service provision contracts so they would know exactly what kinds of healing 'services' would be funded, what 'categories' the healers would have to report to the Directorate through, and the level of detail to which the healers would be expected to report. One contentious decision, for instance, was the omission of herbal remedies (Maori Health Directorate n.d.). To help design the contracts, the Directorate organised an extensive series of hui as part of a consultation process involving Maori healers (most of whom were associated with the national Board) and Maori elders, throughout the country. A Maori Health Directorate (the Maori Health Division of the Ministry of Health) administrator talking with me about these consultation meetings said,

What we [have been doing in these meetings] is talking about the range of traditional healers there are in Maori society. And they range from whare oranga [healers] who ... see themselves as the real deal. They don't like taking any coin [money] for the services they provide ... these are people who just keep on working at it, everyday, generally without any health [sector support] ... [they] just provide services in a real, old, tikanga ${ }^{11}$ [culturally appropriate] way. ... they don't really want a relationship with us. They like to do their own 
thing and they see a relationship with people coming from um, they call it a colonial structure actually, which is quite strange [he said this last phrase quietly and quickly] ... um, they see people like us in the Ministry of Health as tainting the strength of their services.

Interviewer: Is that not just because of money?

Directorate Administrator: The power structure. They see it as taking over.

The idea of funding Maori healing and entwining it within a secular, administrative structure was considered by the 'most traditional' (the words of a senior Maori Health Directorate administrator) healers as a contravention of the ethic of healing. This is because most if not all healers consider Rongoa to be primarily a spiritual activity. It is spiritual power that imbues the healing process with fecundity and power, so steps being taken to establish a human moderator of the healing process are seen as an anathema by most Rongoa practitioners. My experience has shown me that most healers consider the ability to heal to be a gift from Io, or God, and that the only relationships that should come into play during the healing process are the relationships between the healer, the patient(s) and Io. From such a point of view, it may be argued that the integrity of Rongoa would not be 'protected' by the Crown if Rongoa were to be brought directly under government control. 'How can healers have two masters - government and wairua [spirit/uality]?' a healer has asked (Lawson Te Aho 1998:37).

Maori healers are currently required by the Maori Health Directorate to provide a range of diagnostic procedures and healing services that are based on a Maori view of health developed by a clinician and scholar trained in psychiatry, Mason Durie. His view of health is called 'te whare tapa wha' (Durie 1985; Maori Health Directorate n.d.). This phrase is commonly translated as 'the house with four walls. The whare tapa wha represents the notion that each of a house's four walls contributes to the soundness of the whole; if any one wall is weak, the entire structure is weak. Each wall or dimension of the whare tapa wha corresponds to a dimension of health - the spiritual dimension, the psychological dimension, the bodily dimension and the family dimension (Durie 1985).

I suggest the house was chosen as a metaphor because the Maori house, especially the meeting house, has become an artefact replete with significance (Simmons 1997) following Ngata's work with Maoritanga in the early 190os (Sissons 
2000). As a whole and in its parts, the meeting house has social and historical significance and the structure of the house is symbolic of the history of a hapu (sub-tribe) or iwi (tribe) and the structure of the human body - spine, heart, rib cage, and so on. For the healers I worked with, the human body is similarly replete with a social and historical significance. For instance, they had to get 'permission' from not only each patient but each patient's tupuna (ancestors) before proceeding with healing because the body was not only of the patient, but also of the patient's ancestors. The body of the person was also the whare tupuna (ancestral house) of a whakapapa (genealogy). Therefore the patient and the patient's ancestors had a right to say what happened to the body. It was at a healer's peril to engage with the body, or whare tupuna. Without the tupunas' permission the wrath of the ancestors could be incurred if the healer was not welcome. I once witnessed a healer stop healing because, he said, 'it just didn't feel right, they [the patient's ancestors] didn't want me there'.

Durie argues his view of health emerged from narratives collected from Maori elders throughout the country. But I argue the substance of his view also emerged from some other influences (also noted in Schwimmer 2004: 251-253). For instance, Durie notes the similarity of his model to the World Health Organisation's model of health. But 'in contrast' to the wHo's model, Maori emphasise the importance of 'family', which he notes is a specialist subfield of psychiatry (Durie 1985:483). A further contrast to the wHo model Durie identifies is the significance of spirituality to Maori health, noting that spirituality was (then) recently acknowledged as a cultural right of the Maori people by New Zealand's parliamentary and judicial authorities (ibid.: 485).

To me, Durie's work is very much a product of dialogue, and as I noted above, his model is an underpinning of the model of Rongoa developed by the Maori Health Directorate. The concepts of health informing the Rongoa development process are not 'bounded' by an autonomous, unchanging 'Maori culture.' I am not saying this debases the validity of Durie and the Directorate's work. On the contrary, it strengthens it, because Durie and the Directorate are drawing power from other judicial, political and academic authorities and are very much in tune with the current realities, concerns and strengths of today's Maori.

However, the fact that government funded healers are required to work to the whare tapa wha model of health has shut some healers out of the contracting process. Van Meijl (1993) has argued that te whare tapa wha has become hegemonic. Consequently it has silenced much of the heterogeneity of Maori health concepts and prescribed a set of practices that leave some people's needs wanting. That te whare tapa wha has emerged as 'the' Maori view of health may 
well not be an effect intended by Durie given the title of his paper - A Maori Perspective of Health - and also given that in later works he has discussed a number of other models of health too (see Durie 1998). In his initial articulation of a Maori view of health he argued that 'in Maori society the experts on most things are the tribal elders' (Durie 1985:483). However Parsons had noted that significant differences existed between the health concepts, needs and practices of elder and younger Maori (Parsons 1985). In the context of an education programme for school 'dropouts', van Meijl has argued that, many young Maori people considered the views of their elders to be not their own but 'someone else's' (van Meijl 2002: 61). Furthermore, van Meijl found that the young people's personal opinions of Maori culture were not highly valued as a 'model for a cultural identity of Maori people' that has emerged in postcolonial New Zealand (ibid.: 47).

Heterogeneity does not only exist between the older and younger generations. Speaking to me about the government of Rongoa, a healer in her 50 s said to me,

... our people at government have no idea of, I mean they have this traditional healing thing, this national tohunga and their posse,

Interviewer: That Nga Ringa ${ }^{12}$

Healer: [Interrupting me] Yeah, that thing. And you know they said to me why don't you come over here and I said 'No! Because Papa Delamere $^{13}$ [the tohunga of her group] is the bomb!' I stayed right out of that and came up to Auckland. That was because the ones that sit at the Ministry level don't have a true idea. Truly they don't. ... Now I know for a fact that [having worked] in the Ministry ... they live in the tapa wha.

The healers I worked with felt sidelined by the Rongoa development process but disagreed that their model of health was less 'traditional' or worthwhile than te whare tapa wha.

A reason the healers I worked with, who worked according to the Te Oomai Reia ${ }^{14}$ tradition of Maori healing, felt sidelined by the Rongoa contracting process was that they worked with spiritual entities that act to cause illness, heal and underpin good health. The literature on Maori healing shows that the majority of Maori healers consider spiritual powers to have the capacity to cause illness, heal, and underpin wellbeing (eg: Best 1905; Laing 2002; 
Parsons 1985). However, spiritual entities are not acknowledged as legitimate healing powers in Rongoa contracts. Karakia (prayer) is acknowledged as a legitimate mode of healing, but the eradication of kehua (ghosts) is not. When talking with a senior administrator of the Maori Health Directorate about the structure of the health sector within which the contracting of Rongoa had to fit, I raised kehua as an epistemological problem. His response alerted me to the ambiguous positioning of spiritual illness and spiritual healing within the contemporary bicultural model of health sector governance.

Interviewer: ... I guess it might be quite hard to understand from a medical point of view important aspects of traditional Maori healing, like kehua. How do you get around those kinds of issues?

Directorate Administrator: Well ... it's about discretion, and we [Maori] have the right to those things ... and, um, I better come clean. [The healers] really don't have to go into, the fringe stuff ...

The administrator's response shows that bicultural government in health does not readily allow for easy, open and frank communication of the differences between Maori healer's standards and the medical standards they are expected to meet. This is a consequence of an assumption that some issues raised by medical pluralism in New Zealand are simply irresolvable. While the administrator I spoke to can to some extent be inclusive of some 'marginal' healers by accepting silence about some aspects of their practice, we should ask - why is silence necessary? What is keeping some healers from being able to practice a range of traditional Maori healings alongside specialists of biomedicine as equals within New Zealand's state funded health service? From a Treaty principles point of view, who is getting to 'participate' in the nation's health sector and what kinds of intellectual property are being 'protected'? It seems healing kehua related disease, for instance, appears to have the potential to risk other, less fringe healing concepts and practices that have been publicly legitimated by the Rongoa development process.

In my opinion, the current difficulties experienced by administrators of Rongoa are a reflection of the political pressure to put into policy and contracts expectations that do not necessarily match up with many Rongoa healers' conceptions of health, illness and healing. It appears that the model of Maori health to which Rongoa healers are expected to work, needs to be seen by the public health sector leadership as complementary to, as in not too different from, the biomedical model. I contend that the reason for this is that a lay understanding of biomedical logic dominates the majority of health authorities 
and parliamentarian's thinking about health, illness and healing. Furthermore, there appears to be an expectation that the majority of the voting public expects a biomedical logic to drive the nation's health services too. In February 2006, there was an article about Rongoa in a newspaper with a high circulation throughout New Zealand that stated:
'A National Party led government would be unlikely to continue funding traditional Maori therapists using unproven remedies', says the [National] party's health spokesman, Tony Ryall. 'Maori heal- ers using therapies that include prayer, seawater and greenstone ${ }^{15}$ received \$1.3 million a year from the Ministry of Health, although there was no proof the remedies worked ... In terms of the alterna- tive healing mentioned ... I think it's highly unlikely that would continue under National'. Mr Ryall said his party worked on the principle that medicine should be proven ... (NZPA 2006).

A major reason why much, but not all, Maori healing is said to be 'unproven' is that most commentators, such as Tony Ryall, want it to be tested and proven from a biomedical point of view, missing the point that Maori healers do not practice biomedicine. But it must be noted that the Maori Health Directorate appears to be less concerned with proving Rongoa vis-à-vis biomedical standards than ensuring that its contracted healers' work is deemed safe, valuable and effective by the healers' patients, colleagues and acquaintances. Healers must be able to demonstrate these qualities in their quarterly reports back to the Maori Health Directorate. To do this they are required to be monitored by a 'Quality Board' (Maori Health Directorate n.d.) comprised of senior members of the tribe of the region in which they work. A Directorate staff member made reference to the Quality Board evaluation structure as an example of how the Directorate is not 'taking over' but trying to 'find a way of not controlling, but organizing the healers themselves so that they are given an accreditation by the [tribe] of their [region]'. The Quality Board is considered by the Directorate to play a 'moderating' role to ensure that the healers' clients remain safe and that healers respect the traditions of the local Maori people. Hence, the Directorate sees tribal - healer networks as the key to decentralizing authority and regenerating a strong network of Rongoa clinics nationwide. A problem the administrator saw when speaking with me in December 2004 was, 'at the moment, the links with iwi [tribe], are almost non-existent' so these networks need to be regenerated and the national Board plays a key role in this regard. But a further problem I see with this linkage is that some healers may affiliate to more than one tribe and the healers' patients may not affiliate to the tribe of the region in which they receive health care. While tribal linkages may to some 
extent work well for monitoring the specific practices to be followed and needs to be met when healing in a local area, the linkages between tribes, healers and a central governing body will probably bring new issues to the fore. As Sissons (2000:56) has noted, seventy years ago Apirana Ngata found contradictions and ambiguities that were both complicated and useful when constructing a Maoritanga that respected Maori identities at the level of the nation, the tribe and the individual. What will happen, for instance, when a healer and Quality Board do not see 'eye to eye'? What will happen if the clinic's clients back the healer and not the Quality Board? And what will happen when the requirements of the Directorate are not met by a Quality Board? These issues highlight the tensions when questioning where 'sovereignty', or the right to and capacity for self determination, begins and ends for Maori as individuals, a tribal people and a nation of people within a bicultural nation (Fleras and Spoonley 1999; Melbourne 1995).

Before colonization, there was no sense of a universal Maori identity (Durie 2001:57; Walker 2004). But today Maori people share a sufficiently meaningful range of experiences, goals and ways of living to self identify as a nation of Maori people. John Rangihau, a prominent Maori leader and politician during the 1970 s and 1980s, was of the opinion that the notion 'Maori' was designed by Pakeha to facilitate the colonial process (Rangihau 1975). For Rangihau his tribal identity was paramount. The government certainly does use Maori as an official demographic measure for the purposes of government. But iwi (tribe) has also served to facilitate land confiscation and the distribution of Treaty settlement payments (Ballara 1998; Levine 2005). Tribal and pantribal identities have been made and remade as part of, and in response to, the colonial experience. In the 2001 national census, $87 \%$ of descendents of a Maori identified as Maori, and $20 \%$ of Maori did not know to which tribe they were affiliated (Durie 2005:35, 37). Moreover, knowing to which tribe one affiliates does not mean that one actively takes part in tribal life (ibid: 46). For the purposes of administering Rongoa in the present era, though, re-establishing a tribal identity is posed as a means of helping to legitimate the distribution of public resources to a totalized (i.e. tribal and pantribal) diversity of healer practice and patient need. The era in which a tribal identity is the reference point for a sense of belonging for most Maori may be gone, but for certain purposes, such as the dispersal of governing power away from a set of structures dominated by a non-Maori majority, the tribe remains important.

Safety and homogeneity is being pursued through other mechanisms too. The Directorate is refining the philosophical and practical basis of its contracted healers' work by engaging alongside Nga Ringa Whakahaere o te Iwi Maori an 
organization headed by Maori biomedical doctors to develop and administer a course for Rongoa practitioners entitled 'Studies in Maori Traditional Healing' (National Maori Workforce Development Organisation 2001: item 1). The purpose of the course is to improve[e] the consistency and standard of [Rongoa] services'. The specifications for the programme state that, 'trainees will be encouraged to work in a complementary and collaborative manner alongside ... Maori communities, primary care and other publicly funded health services' (National Maori Workforce Development Organisation 2001: item 2). Hence, healers who work in a way that is not complementary to biomedical standards are likely to be marginalized by the Maori Health Directorate's Rongoa development process. Certainly, the standards of Nga Ringa Whakahaere o te Iwi Maori will also be apparent in the complementary model of Maori traditional healing that emerges from the development process, as will the needs and interests of the more vocal of 'Maori communities' represented at the National Maori Workforce Development Organisation's hui. However, I have shown that concepts of illness, healing and health that have already been validated in the public sector tend to marginalise those concepts that have not. I therefore expect the standards of Nga Ringa Whakahaere o te Iwi Maori and 'Maori communities' to be less authoritative in the national model. Aspiring healers will be encouraged to practice according to the national model, as opposed to a personally, whanau or spiritually inspired model, through the prospect of earning a qualification and a job in the public sector.

To conclude, what I have shown is how a Treaty of Waitangi based biculturalism has played out through the development of publicly funded Rongoa services. I have shown that silenced by the 'partnership', 'participation' and 'protection' ideals of biculturalism are concepts, practices and relationships that say much about how cultural pluralism has been managed by the contemporary government of Rongoa. Speaking in terms of the Treaty's principles, the 'Crown', through the Maori Health Directorate, has partnered with Maori healers who are able to work with concepts of health, illness and healing that are complementary to Western medical notions of health, illness and healing. ${ }^{16}$ It has been only 'complementary' Rongoa healers who have been able to 'participate' as paid up members of New Zealand's publicly funded health services. The kind of Rongoa that has been 'protected' by the Crown has been the forms of Rongoa that are complementary to Western medicine. The government is not actively suppressing other forms of Rongoa, but the ongoing 'protection' of 'un-complementary' forms has been left to healers who are not being resourced by the Crown which arguably, thereby, also imbues their concepts and practices with less legitimacy than funded Rongoa. 
Some of the difficulties the government's administrators (and healers) have had to contend with when developing a publicly fundable form of Rongoa are political pressures to write into health policy and health service contracts dictates for practice that do not necessarily match up with preferred, though marginalized, concepts of health, illness and healing. It seems that for Rongoa to form part of New Zealand's publicly funded health system it must be complementary to, as in different but not too different from, the kinds of health concepts that have already been validated by government process. The weight of bicultural politics and Western medicine's dominance of the health sector appeared to set limits around how Rongoa healers take on the public purse could be justified, and therefore how Rongoa could proceed into the future as a government funded health service.

\section{NOTES}

1 This paper is drawn from my work towards a PhD in Anthropology at the University of Auckland, New Zealand. A shorter version of this paper was presented at the 2005 Anthropology Association of Aotearoa/ New Zealand annual conference held at Victoria University of Wellington, New Zealand, 2005, and at the Society for Medical Anthropology annual conference held in Vancouver, 2006.

2 The 'articles' are too long to repeat here but the 'principles' of the Treaty's articles and preamble will be discussed below.

3 George Salmond also said in the same minute: 'The Department accepts this view [of particular 'Maori' health needs and rights] which is in accord with the wHo principles set out in the Alma Ata Declaration of 1978 on Primary Health Care' (cited in Durie 1998: 205).

4 There are English and Maori language versions of the Treaty and most Chiefs signed the Maori version. The English and Maori versions of the Treaty do not say the same things.

5 Aoteaora is the Maori name for New Zealand.

6 It has been argued that the reason why the Act was passed may have less to do with targeting tohunga in general than targeting the tohunga, prophet and millennial movement leader, Rua Kenana, in particular because Kenana foresaw an age when Pakeha would be thrown from the land (Voyce 1989). 
7 However, it is reasonable to expect that for many if not all Maori healers of the early twentieth century the collection, preparation and administration of herbal remedies and the act of physically manipulating the body required karakia or the invocation of spiritual power (Best 1905). It is commonplace for today's Maori healers to use karakia or invoke spiritual powers for these purposes (e.g. Jones 2000a; McGowan 2000; Parsons 1985). I thank one reviewer for pointing out the need to clarify this point.

8 Land confiscations began in the late $19^{\text {th }}$ century and continued well into the twentieth, many of which been deemed illegal by the Waitangi Tribunal (www. waitangitribunal.govt.nz). With the passing of the Foreshore and Seabed Act in 2004, some commentators have argued that colonial land confiscations are in fact continuing (e.g. Turei 2005).

9 A survey of Auckland GPs carried out in 1990 found that thirty percent of the respondents practised one or more forms of 'alternative' medicine. Two-thirds reported they would refer patients for alternative treatment (Marshall et al 1990). In 2003 the Ministry of Health said the majority of complementary or alternative (CAM) practitioners are in private practice and these practitioners usually have some training in one or more CAM modalities. Some CAM practitioners work from clinics that may also offer mainstream medical services (available online, 31 March 2007 http://www.newhealth.govt.nz/maccah/providers.htm\#_edn3).

The Accident Compensation Corporation (ACC) administers New Zealand's accident compensation scheme, which provides personal injury cover for all New Zealand citizens, residents and temporary visitors to New Zealand. In return people do not have the right to sue for personal injury, other than for exemplary damages. The ACC funds the following types of health care providers: Acupuncturists, audiologists, chiropractors, counselors, dentists, medical laboratory technologists, nurses, occupational therapists, optometrists, osteopaths, physiotherapists, podiatrists, medical practitioners, speech therapists. (available online 31 March 2007: http://www.acc.co.nz/wcmoo1/idcplg?IdcService=SS GET_PAGE\&nodeId=4226\&ssSourceNodeId=3879).

10 A label some, if not most, Rongoa healers would reject: 'This isn't 'alternative', a healer told me, 'it's normal.'

11 Tikanga is defined by Hirini Mead as 'the set of beliefs associated with practices and procedures to be followed in conducting the affairs of a group or an individual' (Mead 2003:12). 
12 Nga Ringa Whakahaere o te Iwi Maori - the National Board of Maori healers.

13 I name Papa Delamere for several reasons. First, Papa was happy to be named in this paper. Second, that Papa Delamere was the tohunga of the Te Oomai Reia Maori healing tradition was widely known among people involved in the field of Maori healing throughout the country. Third, because I have conducted a contextualised analysis of Maori healing, in that I speak of a particular tradition of Maori healing, one cannot speak about Te Oo Mai Reia in the Auckland region without reference to Papa Delamere.

14 Te Oomai Reia is a heterogeneous healing tradition which, as far as I am aware, is based primarily on the teachings of Papa Delamere (see for example www. healing4u.biz). However there are many parallels between the Te Oomai Reia healers concepts and practices and those of other Maori healers (see for example Jones 2000c, McLeod 1999) and some 'New Age' healers (see for example Chopra 1990; Heelas 1996).

15 Greenstone looks like jade. Seawater and greenstone are considered to have spiritual properties.

16 This does not ensure that when speaking about 'an illness', however, a Rongoa healer and a medical doctor will be referring to the same thing.

\section{REFERENCES}

Ballara, A. 1998 Iwi: The Dynamics of Maori Tribal Organisation from c.1769 to c.1945, Wellington: Victoria University Press.

Belgrave, M., Kawharu M., and Williams, D. 2005 Waitangi Revisited: Perspectives on the Treaty of Waitangi, Auckland and Melbourne: Oxford University Press.

Best, E. 1904 'Maori medical lore', Journal of the Polynesian Society, 13(52): 213237.

Best, E. 1904 Maori medical lore, Journal of the Polynesian Society, 14(53):1-23.

Black, N. Boswell, D. Gray, A. Murphy, S and Popay, J (eds) 1988 Health and Disease: A Reader, Milton Keynes: Open University Press.

Bozic-Vrbancic, S. 2003 'One nation, two peoples, many cultures: exhibiting iden- 
tity at Te Papa Tongarewa', Journal of the Polynesian Society, 112(3):307-313.

Brookfield F. M. J. 1999 Waitangi and Indigenous Rights: Revolution, Law and Legitimation, Auckland: Auckland University Press.

Buck, Sir P. 1950 The Coming of the Maori. 2nd edition. Wellington: Maori Purposes Fund Board: Whitcombe and Tombs.

Chopra, D. 1990 Quantum Healing: Exploring the Frontiers of Mind/Body Medicine, New York, Toronto, London, Sydney and Auckland: Bantam Books.

Department Of Maori Affairs, 1960 Report of the Board of Maori Affairs Secretary, Department of Maori Affairs and the Maori Trustees, Wellington: Department of Maori Affairs.

Dew, K. 2003 Borderland Practices: Regulating Alternative Therapies in New Zealand, Dunedin: University of Otago Press.

Dow, D. 1995 Safeguarding the Public Health: A History of the New Zealand Department of Health, Wellington: Victoria University Press.

Dow, D. 1999 Maori Health \& Government Policy 1840 - 1940, Wellington: Victoria University Press in association with the Historical Branch Dept. of Internal Affairs.

Durie, M. 1985 'A Maori perspective of health', Social Science and Medicine, $20(5): 483-486$.

Durie, M. 1998 Whaiora: Maori Health Development, Auckland: Oxford University Press.

Durie, M. 2001 Mauri ora: the dynamics of Maori health, Auckland: Oxford University Press.

Durie, M. 2005 Nga Tai Matatu: Tides of Maori Endurance, Auckland: Oxford University Press.

Durie, M. Potaka, U. Ratima, K.H. and Ratima M.M. 1993. Traditional Maori healing: A paper presented for the National Advisory Committee on Core Health and Disability Services. Palmerston North: Department of Maori Studies, Massey University. 
Fleras, A. and Spoonley, P. 1999 Recalling Aotearoa: Indigenous Politics and Ethnic Relations in New Zealand, Auckland and Melbourne: Oxford University Press.

Foucault, M. 1991 'Governmentality’ in C. Gordon and P. Miller (eds) The Foucault Effect: Studies in Governmentality, Hemel Hempstead, Hertfordshire: Harvester Wheatsheaf: 87-104.

Gramsci, A. 1971 Selections from the Prison Notebooks of Antonio Gramsci, New York: International Publishers.

Heelas, P. 1996 The New Age Movement: The Celebration of the Self and the Sacralization of Modernity, Cambridge, Mass.: Blackwell Publishers.

Jones, R. 20ooa. 'Traditional Maori healing', Pacific Health Dialog, 7(1)107-109.

Jones, R. 200ob Rongoa Maori and Primary Health Care, MPH thesis. University of Auckland.

Jones, R. 2000c 'Diagnosis in traditional Maori healing : a contemporary urban clinic', Pacific Health Dialog, 7(1):17-24.

Kolig, E. 2004 'Deconstructing the Waitangi Treaty narrative: democracy, cultural pluralism, and political myth making in New Zealand/Aotearoa', Sites 1(2): 84-117.

Laing, P. 2002 'Spirituality, belief and knowledge' in W. Ernst (ed) Plural Medicine, Tradition and Modernity, 1800-2000, New York: Routledge:153-170.

Lawson - Te Aho, K. 1998 Service Evaluation of Te Whare Whakapikiora o te Rangimarie, Wellington: Central Health, Health Funding Authority.

Levine, H. 2005 'Moving Beyond Cultural Essentialism' in J. Liu, T. McCreanor and T. McIntosh (eds) New Zealand Identities: Departures and Destinations, Wellington: University of Victoria Press: 104-117.

Linnekin, J. 1983 'Defining tradition: variations on the Hawaiian identity', American Ethnologist 10(2): 241-52.

Maori Health Directorate, 2004 Whakatataka: Project Plan: Building on Maori Models of Health: Rongoa Traditional Healers, Wellington. 
Maori Health Directorate (n.d.) Rongoa Maori Traditional Healing Services, Wellington.

Marshall R. Gee, R. and Israel, M. 1990 'The use of alternative therapies by Auckland general practitioners', New Zealand Medical Journal, 103: 213-15.

Mead, H. 2003 Tikanga Maori: Living by Maori values, Wellington: Huia Publishers.

Melbourne, H. 1995 Maori Sovereignty: The Maori Perspective, Auckland: Hodder Moa Beckett.

Metge, J. 1964 A New Maori Migration: Rural and Urban Relations in Northern New Zealand, London: Athlone Press.

McGowan, R. 2000 'The Contemporary Use of Rongoa Maori, Traditional Maori Medicine', unpublished MA Thesis, University of Waikato.

McLeod, M. 1999 'E Iti Noa Na te Aroha: A Qualitative Exploration into the Realms of Maori Healing', Unpublished MA Thesis, University of Waikato.

Ministry Of Health, 2000 New Zealand Health Strategy, Wellington, New Zealand www.moh.govt.nz

Ministry of Health 2005 The New Zealand Public Health and Disability Act 2000. 31 March 2007 http://www.moh.govt.nz/moh.nsf/pagesmh/1375?Open

Ministry Of Health, 2003 Complementary and Alternative Medicine: Current Policies and Policy Issues in New Zealand and Selected Countries. A discussion document, 31 March 2007 www.newhealth.govt.nz/maccah.htm

MinistryOfHealth, 2005NewZealandPublic HealthandDisability Act,31 March 2007 http://www.moh.govt.nz/moh.nsf/70o4beoc19a98f8a4c25692eoo7bf833/ e65f72c8749e91e74c2569620ooob7ce?OpenDocument

Ministry Of Health 2006 Taonga Tuku Iho - Treasures of Our Heritage: Rongoa Development Plan. Wellington, New Zealand: Ministry of Health.

Ministry Of Justice 2006 The New Zealand Legal System, 30 September 2006 http://www.justice.govt.nz/pubs/other/pamphlets/2001/legal_system.html 
National Maori Workforce Development Organisation 2001 Service Specification for Rongoa Maori, Greenlane, Auckland. @www.hauora.com

NZPA, 2006 National says it would stop funding Maori therapists. The New Zealand Herald, 23 February. @ www.nzherald.co.nz/topic/story.cfm?c_ id=252\&objectid=10364911

Orange, C. 1987 The Treaty of Waitangi, Wellington: Allen and Unwin.

Parsons, C. 1985 'Notes on Maori sickness knowledge and healing practices', in C. Parsons (ed) Healing practices in the South Pacific, Brigham Young University, Hawaii: Institute for Polynesian Studies: 213-234.

Pomare, E. and de Boer G.M. 1988 Hauora. Maori Standards of health. A study of the years 1970-1984, Wellington, Medical Research Council: Dept of Health.

Rangihau, J. 1975 'Being Maori', in M. King (ed) Te Ao Hurihuri: The World Moves On, Wellington: Hicks Smith and Sons: 221-233.

Rata, E. 2004 'Marching through the institutions': the neotribal elite and the Treaty of Waitangi', Sites 1(2):57-83.

Rata, E. 2005 'Rethinking Biculturalism', Anthropological Theory, 5(3):267-284.

Reid, P. Robson, B. and Jones, C.P. 2000 Disparities in health: common myths and uncommon truthes. Pacific health dialog 7(1):38-47.

Salmond, G. and Hodge J. 1988 'Foreword', in E. Pomare and G. de Boer (eds) Hauora: Maori Standards of Health. A Study of the Years 1970-1984, Wellington: The Department of Health and the Medical Research Council.

Schwimmer, E. 2004 'Making a world: the Maori of Aotearoa/New Zealand' in J. Clammer, S. Poirier and E. Schwimmer (eds) Figured Worlds: Ontological Obstacles in Intercultural Relations, Toronto, Buffalo and London: University of Toronto Press: 243-276.

Simmons, D. 1997 The Maori Meeting House: Te Whare Runanga. Auckland: Reed. 
Sissons, J. 1993 'The systematisation of tradition: Maori culture as a strategic resource', Oceania, 64(2): 97-117.

Sissons, J. 1998 'Introduction: Anthropology, Maori tradition and colonial processes', Oceania, 69(1):1-3.

Sissons, J. 2000 'The post-assimilationist thought of Sir Apirana Ngata: towards a genealogy of New Zealand biculturalism', New Zealand Journal of History, 34(1).

Sissons, J. 2005 'Beware the Maori Elite: A reply to Christopher Tremewan's 'Ideologlical conformity: A fundamental challenge to the social sciences in New Zealand", Sites, 2(1): 28-32.

Te Puni Kokiri, 2001 He Tirohanga ö Kawa ki te Tiriti o Waitangi: A Guide to the Principles of the Treaty of Waitangi, Wellington.

Turei, M. 2005 General Debate: Seabed and Foreshore. Green Party of Aotearoa New Zealand @ http://www.greens.org.nz/searchdocs/speech8468.html

Walker, R. 1996 Nga Pepa a Ranginui: The Walker Papers, Auckland: Penguin Books.

Walker, R. 2004 Ka Whawhai Tonu Matou: Struggle Without End, Auckland: Penguin Books.

Webster, S. 1998 Patrons of Maori Culture: Power, Theory and Ideology in the Maori Renaissance, Dunedin: University of Otago Press.

Williams, H. 2003 [1844] Dictionary of the Maori Language, Wellington: Legislation Direct.

World Health Organisation, 1977, The Promotion and Development of Traditional Medicine. Geneva.

van Meijl, T. 1993 'Maori perspective on health and its politicization', Medical Anthropology, 15(3):283-297.

van Meijl, 2002 'Culture and crisis in Maori society: The tradition of the other and the displacement of self', in E. Kolig and H. Muckler (eds) Politics of 
Article $\cdot$ O'Connor

Indigeneity in the South Pacific: Recent Problems of Identity in Oceania, Hamburg: Lit Verlag: 47-71.

Voyce, M. 1989 'Maori healers in New Zealand: The Tohunga Suppression Act 1907', Oceania, 6o(2): 99-123. 